\title{
Field and Greenhouse Evaluations of Cucurbit Rootstocks to Improve Verticillium Resistance for Grafted Watermelon
}

\author{
Jesse Wimer \\ Department of Horticulture, Northwestern Washington Research and \\ Extension Center, Washington State University, Mount Vernon, WA 98273
}

\author{
Debra Inglis \\ Department of Plant Pathology, Northwestern Washington Research and \\ Extension Center, Washington State University, Mount Vernon, WA 98273
}

Carol Miles ${ }^{1}$

Department of Horticulture, Northwestern Washington Research and Extension Center, Washington State University, Mount Vernon, WA 98273

Additional index words. Verticillium dahliae, grafting, Lagenaria siceraria, Citrullus lanatus, cucurbit rootstocks

\begin{abstract}
Grafting watermelon (Citrullus lanatus Thunb.) onto resistant rootstocks is used in many areas of the world to overcome soilborne disease losses including verticillium wilt caused by Verticillium dahliae Kleb. Currently, this disease poses a serious risk to watermelon growers in Washington State. To identify resistant rootstocks, the verticillium wilt reactions (chlorosis, necrosis, and wilting) of 14 nongrafted PI accessions including Benincasa hispida Thunb., Cucurbita moschata Duchesne ex Poir., and Lagenaria siceraria Molina Standl. from the U.S. Department of Agriculture National Plant Germplasm System (USDA NPGS); 11 nongrafted commercially available rootstocks; and, nongrafted 'Sugar Baby' watermelon (verticillium wilt-susceptible control) were visually assessed in a field naturally infested with $V$. dahliae at a rate of 17 colony-forming units (cfu) per gram of soil. Typical symptoms of verticillium wilt were observed on all entries. 'Sugar Baby' had the highest relative area under disease progress curve (RAUDPC) value (26.80), which was not significantly different from '64-19 RZ', 'Marvel', PI 368638, PI 634982, and PI 642045 (average $=10.16$ ). PI 419060 (1.46) had the lowest RAUDPC value, which was not significantly different from 'Miniature Bottle Gourd', PI 326320, PI 419016, PI 536494, PI 636137, 'Strong Tosa', 'Strongtosa', and 'TZ 148' (average = 3.36). The mean RAUDPC value of PI accessions (5.49) did not differ significantly from the mean value of the commercial rootstocks (5.68). Microsclerotia typical of Verticillium spp. were observed in the stems of all but one entry (PI 181913). In a greenhouse study, a subset of 12 entries were inoculated with $V$. dahliae, and by 22 days after inoculation (DAI), 'Sugar Baby' had a significantly higher disease rating than all entries except PI 419060, PI 438548, and 'Titan'. A strong positive correlation was observed between the field and greenhouse studies. Results indicate that commercial rootstocks as well as PI accessions could be used to successfully manage verticillium wilt in Washington; however, grafting compatibility with watermelon must first be ascertained for the promising PI accessions. Although greenhouse-based verticillium wilt assays can be used to help predict rootstock performance in the field, accurate assessment may require manipulating environmental conditions (e.g., temperature and humidity) to approximate field conditions.
\end{abstract}

Throughout the 20th century, watermelon (C. lanatus Thunb.) grafting was adopted in many areas of the world to manage soilborne

Received for publication 24 June 2015. Accepted for publication 28 Aug. 2015.

We thank the National Plant Germplasm System, Rijk Zwaan, Syngenta, Takii Seed, Osbourne Seed, De Ruiter, and Clouse Seeds for donating the seed used in this experiment. Funding support from the Washington State Department of Agriculture Specialty Crop Block Grant Program and the Washington State University Emerging Research Issues Extension grant are gratefully acknowledged. ${ }^{1}$ Corresponding author. E-mail: milesc@wsu.edu.
$V$. dahliae has a wide host range and can persist in the soil for long periods (Berlanger and Powelson, 2000). Farmers have traditionally used soil fumigation to control this pathogen, but some products (e.g., methyl bromide) are no longer available, whereas others have questionable efficacy (Klosterman et al., 2009; U.S. Environmental Protection Agency, 2013; Woodward et al., 2011). Thus, grafting onto disease-resistant or -tolerant rootstocks may be the only feasible way to manage severe infestations.

The first step in developing a successful management strategy for verticillium wilt in watermelon via the use of grafted plants is to evaluate rootstocks for resistance to $V$. dahliae. Paplomatas et al. (2000) are the only researchers to date that have carried out such an experiment. These researchers screened 33 cucurbit rootstocks for resistance to $V$. dahliae in Greece and found some degree of tolerance in zucchini, pumpkin, and bottle gourd, but none of the tested rootstocks were resistant. Of the many commercial watermelon rootstocks on the market, none have been sufficiently tested for verticillium wilt resistance or tolerance in Washington. The USDA NPGS contains over 1000 PI accessions in the Cucurbit family, including several genera and species that are used for commercial rootstocks for watermelon. Among these are B. hispida Thunb., Cucurbita maxima Duchesne, $C$. moschata Duchesne ex Poir., and L. siceraria Molina Standl. There are additional genera and species that may be suitable for use as rootstocks, but are so far untested. An extensive search for PI accessions with resistance or tolerance to specific pathogens is much needed and could result in the development of affordable and regionally adapted rootstocks in the United States (Lee et al., 1998).

Although Paplomatas et al. (2002), Paroussi et al. (2007), Buller et al. (2013), and Wimer et al. (2015) have demonstrated that grafting can significantly reduce verticillium wilt of watermelon, no commercial growers in Washington are currently using grafted plants to manage this disease. Adoption of this practice is hindered by the increased costs of grafted seedling production attributed to the extra (and often expensive) seed needed to grow the rootstock, the labor needed to perform the grafting and care for the grafted seedlings, and the special facilities that are required for proper graft union formation (Boughalleb et al., 2007; King et al., 2010; Lee et al., 2010). In addition, there is currently a lack of published information regarding the performance of commercially available rootstocks in specific environments (Kubota et al., 2008). For large-scale growers in Washington (each of whom requires tens of thousands of plants), adoption of this practice is contingent on the resolution of these issues.

To identify verticillium wilt-resistant rootstocks, an efficient disease evaluation system is needed. Field assays can be used for this purpose, but they tend to be lengthy and confined to each growing season's 
constraints (Bae et al., 2011). Greenhouse assays, however, are rapid and can be conducted most times of the year. Bae et al. (2011) developed a greenhouse assay to screen potato seedlings for verticillium wilt and demonstrated that resistance, tolerance, and susceptibility to this disease can be accurately assessed. The protocol used in the Bae et al., study involved submerging exposed roots into a $V$. dahliae suspension. Dervis et al. (2009), Boughalleb et al. (2007), Paplomatas et al. (2000), and others used a similar procedure to test the pathogenicity of various pathogens on multiple cucurbit crops in the greenhouse. Although such greenhouse studies can be useful in determining resistance, tolerance, or susceptibility, the correlation with field studies can vary considerably (Zhang et al., 1997). Thus, greenhouse assays that can be used to predict field performance need to be developed to ensure cost-effective and efficacious rootstock development.

One objective of this study was to identify commercially available rootstocks and PI accessions that could be used to manage verticillium wilt of watermelon in Washington. The second objective was to compare the verticillium wilt reactions of entries in field and greenhouse assays. To achieve these objectives, plants were first evaluated in a field naturally infested with $V$. dahliae, then in the greenhouse using artificial inoculation.

\section{Materials and Methods}

Field conditions. The field study was conducted during the summer of 2013 at Washington State University (WSU) Mount Vernon. The soil type is Skagit silt loam, a fine-silty mixed nonacid mesic Typic Fluvaquents (University of California, 2010). The soil $\mathrm{pH}$ was 6.1 (saturated paste) and the organic matter content was $29 \mathrm{~g} \cdot \mathrm{kg}^{-1}$ soil (loss of ignition). The summer climate is cool and humid, with an average daily temperature of $16{ }^{\circ} \mathrm{C}\left(22{ }^{\circ} \mathrm{C}\right.$ maximum and $11{ }^{\circ} \mathrm{C}$ minimum, on average), and $81 \%$ relative humidity $(\mathrm{RH})$. Total precipitation during this study was $94 \mathrm{~mm}$ (AgWeatherNet, 2013).

Soil assay for $V$. dahliae. The study site had a history of natural infestation of $V$. dahliae at a rate of $18.0 \mathrm{cfu} / \mathrm{g}$ soil (Buller et al., 2013). To measure the current infestation level, 20 random samples were taken from the experimental field to a depth of $15 \mathrm{~cm}$. Samples were bulked and placed in the greenhouse to dry (Harris et al., 1993). Once dry, $1 \mathrm{~g}$ subsamples were uniformly distributed onto 10 plates of NP-10 media using a salt shaker, a method that is a modification of the Butterfield and DeVay (1977) method which distributes soil onto plates via an Anderson Sampler. Following incubation, colonies of $V$. dahliae were counted with the aid of a dissecting microscope $(\times 40)$ and the population density was calculated to be $17.0 \mathrm{cfu} / \mathrm{g}$ of soil.

Plant material. There were 26 entries planted in the field study (Table 1). Eleven of the entries were commercially available watermelon rootstocks, 14 were PI accessions obtained from the USDA NPGS, and one was 'Sugar Baby', a verticillium wiltsusceptible watermelon control (Elena, 2000). All entries were grown from seed at WSU Mount Vernon. Seeds were sown in potting mix (Sunshine \#3 N and O; Sun Gro Horticulture, Agawam, MA) in 72-celled trays between 28 May and 3 June (the different sowing dates were based on receipt of seeds).

Field experiment establishment. On 3 June, fertilizer (Wil-Gro Organic fertilizer 8N-0.9P3.3K; Wilbur-Ellis, Mount Vernon, WA) was broadcast at a rate of $78 \mathrm{~kg} \mathrm{~N} /$ ha over bed centers and raised beds were then formed using a bed shaper (Rain-Flo 2600; Rain-Flo Irrigation, East Earl, PA). The beds were $0.25 \mathrm{~m}$ tall, $0.9 \mathrm{~m}$ wide, and $3 \mathrm{~m}$ center to center and covered with black plastic mulch (0.025 mil embossed; Pliant Corporation, Washington, GA). Irrigation drip tape (low flow, $16 \mathrm{~mm}$ diameter, $0.2 \mathrm{~mm}$ wall thickness, $20 \mathrm{~cm}$ emitter spacing; John Deere, San Marcos, CA) was located on the center of each bed underneath the plastic.

Transplanting into the field occurred between 12 and 21 June when the plants had 2-4 true leaves, with the three replications of any given entry being planted on the same day. Drip irrigation commenced on 1 July and continued at a rate of $25 \mathrm{~mm}$ of water per week through July and every 3 weeks thereafter to promote the onset of disease symptoms (Cappaert et al., 1994). Fertilizer
(5N-0.9P-0.8K; Converted Organics, Gonzales, CA) was applied through the irrigation system at a rate of $4-5 \mathrm{~kg} \mathrm{~N} / \mathrm{ha}$ per week through July and every 3 weeks thereafter for the remainder of the growing season.

Plant disease ratings and pathogen detection. Field plots were rated visually for verticillium wilt severity on a weekly basis from 2 Aug. to 18 Sept. Disease severity was recorded as the percent of the plot canopy displaying chlorosis, necrosis (in the form of $\mathrm{V}$-shaped lesions), and wilting. Stem samples were assayed for Verticillium spp. using the techniques outlined by Buller et al. (2013). Following incubation, samples were analyzed for microsclerotia and pure cultures were obtained from infested stems using NP-10 agar medium (Kabir et al., 2004). Seven of the cultures based on rootstock diversity were selected for species identification at WSU Molecular Biosciences Laboratory (Table 2).

Greenhouse assays. Twelve entries were selected for a greenhouse inoculation study based on species diversity and variation in verticillium wilt reactions. The entries included 'Sugar Baby' as the verticillium wilt-susceptible watermelon control; the commercial rootstock cultivars Tetsukabuto, Titan, Marvel, and Strongtosa; and NPGS accessions PI 326320, PI 419016, PI 419060, PI 438548, PI 536494, PI 636137, and PI 181913. This study was carried out from Mar. to May in 2014 (average daily temperature $22{ }^{\circ} \mathrm{C}, 24{ }^{\circ} \mathrm{C}$ maximum and $20^{\circ} \mathrm{C}$

Table 1. Species and source of each cucurbit cultivar and accession included in the verticillium wilt field screening study at Washington State University Mount Vernon Northwestern Washington Research and Extension Center in 2013.

\begin{tabular}{|c|c|c|}
\hline Entry & Species & Source $^{z}$ \\
\hline \multicolumn{3}{|l|}{ Watermelon cultivar } \\
\hline Sugar Baby & Citrullus lanatus & Osborne Seed \\
\hline \multicolumn{3}{|l|}{ Commercial Rootstock } \\
\hline 64-19 RZ & Cucurbita maxima & Rijk Zwaan \\
\hline Emphasis & Lagenaria siceraria & Syngenta \\
\hline Marvel & Cucurbita hybrid & Takii Seed \\
\hline Miniature Bottle Gourd & L. siceraria & Osborne Seed \\
\hline Rampart & Lagenaria $\mathrm{sp}$. & Takii Seed \\
\hline RS 841 & Cucurbita hybrid & De Ruiter \\
\hline Strongtosa & Cucurbita sp. & Osborne Seed \\
\hline Strong Tosa & Cucurbita hybrid & Syngenta \\
\hline Tetsukabuto & Cucurbita hybrid & Takii Seed \\
\hline Titan & Cucurbita hybrid & Takii Seed \\
\hline TZ 148 & Cucurbita hybrid & Clause Seeds \\
\hline \multicolumn{3}{|l|}{ PI accession } \\
\hline PI 181913 & L. siceraria & PGRCU (Syria, 1949) \\
\hline PI 326320 & Cucurbita moschata & PGRCU (United States, 1968) \\
\hline PI 368638 & L. siceraria & PGRCU (Macedonia, 1971) \\
\hline PI 381820 & C. moschata & PGRU (India, 1973) \\
\hline PI 419016 & Benincasa hispida & PGRU (China, 1977) \\
\hline PI 419060 & B. hispida & PGRU (China, 1977) \\
\hline PI 419123 & B. hispida & PGRU (China, 1977) \\
\hline PI 438548 & C. moschata & PGRCU (Belize, 1979) \\
\hline PI 482490 & C. moschata & PGRCU (Zimbabwe, 1983) \\
\hline PI 536494 & C. moschata & PGRCU (Maldives, 1986) \\
\hline PI 604505 & C. moschata & PGRCU (Pennsylvania, 1961) \\
\hline PI 634982 & C.a moschata & PGRCU (United States, 1980) \\
\hline PI 636137 & L. siceraria & PGRCU (India, 1993) \\
\hline PI 642045 & L. siceraria & PGRCU (Georgia, United States, 2006) \\
\hline
\end{tabular}

${ }^{\text {z }}$ Source is a commercial supplier or the National Plant Germplasm System located at the Plant Genetic Resources Unit in Geneva, NY, or the PGRCU located in Griffin, GA. Country of origin and collection date given in parentheses for PI accessions. 
Table 2. Final verticillium wilt severity ratings and relative area under disease progress curve (RAUDPC) values for each cucurbit cultivar and accession included in the verticillium wilt field screening study at Washington State University Mount Vernon Northwestern Washington Research and Extension Center in 2013.

\begin{tabular}{|c|c|c|}
\hline Entry & Severity $(\%)^{z}$ & RAUDPC $^{\mathrm{y}}$ \\
\hline \multicolumn{3}{|l|}{ Watermelon cultivar } \\
\hline Sugar Baby & 98 & $26.80 \mathrm{a}$ \\
\hline \multicolumn{3}{|l|}{ Commercial rootstock } \\
\hline 64-19 RZ & 28 & $7.14 \mathrm{abc}$ \\
\hline Emphasis & 17 & $5.20 \mathrm{cde}$ \\
\hline Marvel & 33 & $14.57 \mathrm{a}$ \\
\hline Miniature Bottle Gourd & 12 & $2.26 \mathrm{fg}$ \\
\hline Rampart & 20 & $5.66 \mathrm{bcd}$ \\
\hline RS 841 & 28 & $5.85 \mathrm{bcd}$ \\
\hline Strong Tosa & 28 & 3.84 cdefg \\
\hline Strongtosa & 33 & 4.00 cdefg \\
\hline Tetsukabuto & 28 & $5.15 \mathrm{cde}$ \\
\hline Titan & 23 & 4.82 cde \\
\hline TZ 148 & 20 & 3.97 cdefg \\
\hline \multicolumn{3}{|l|}{ Germplasm accession } \\
\hline PI 181913 & 19 & $5.43 \mathrm{bcd}$ \\
\hline PI 326320 & 12 & 4.27 cdefg \\
\hline PI 368638 & 67 & $10.84 \mathrm{ab}$ \\
\hline PI 381820 & 24 & $5.49 \mathrm{bcd}$ \\
\hline PI 419016 & 4 & $2.39 \mathrm{fg}$ \\
\hline PI 419060 & 6 & $1.46 \mathrm{~g}$ \\
\hline PI 419123 & 16 & $5.71 \mathrm{cdef}$ \\
\hline PI 438548 & 11 & $4.73 \mathrm{cdef}$ \\
\hline PI 482490 & 35 & $5.89 \mathrm{bcd}$ \\
\hline PI 536494 & 13 & $3.33 \mathrm{defg}$ \\
\hline PI 604505 & 38 & $6.21 \mathrm{bcd}$ \\
\hline PI 634982 & 32 & $6.85 \mathrm{abc}$ \\
\hline PI 636137 & 8 & $2.84 \mathrm{efg}$ \\
\hline PI 642045 & 65 & $11.42 \mathrm{ab}$ \\
\hline Average & 28 & 6.39 \\
\hline$P$ value ${ }^{\mathrm{x}}$ & $<0.0001$ & $<0.0001$ \\
\hline
\end{tabular}

${ }^{\mathrm{z} T h e}$ field site was naturally infested with Verticillium dahliae at a rate of $18.0 \mathrm{cfu} / \mathrm{g}$ of soil. Final verticillium wilt severity ratings were taken on 18 Sept.; severity was recorded as the percent of the plot canopy displaying typical verticillium wilt symptoms: chlorosis, necrosis, and wilting.

${ }^{y}$ RAUDPC values were calculated by dividing area under disease progress curve (AUDPC) values by the maximum potential AUDPC. The maximum potential AUDPC was calculated as (final rating date transplant date) $\times 100($ Fry, 1978) .

${ }^{x}$ The data for both severity and RAUDPC violated the assumptions of ANOVA and therefore required transformation. PROC RANK in SAS (Version 9.2, SAS Institute, Cary, NC) was used in all cases, and ranked data from each site was compared separately using PROC GLM with $\alpha=0.05$. However, the means presented in the table are nontransformed. Fisher's LSD test was used to locate differences in RAUDPC values among treatments. RAUDPC values followed by the same letter within a column are not significantly different at $\alpha=0.05$.

minimum; RH 40\%) and repeated from Jan. to Mar. in 2015 (average daily temperature $21{ }^{\circ} \mathrm{C}, 24{ }^{\circ} \mathrm{C}$ maximum and $20^{\circ} \mathrm{C}$ minimum; RH $42 \%$ ). All plants were started from seed following the methods described above. Seedlings were inoculated at the 1-2 true leaf stage on 9 Apr. in 2014 and 2 Feb. in 2015 with the $V$. dahliae isolate 'JAW13127' (isolated from 'Sugar Baby' in the field study) using the root-dip method and a conidial suspension of $10^{6} / \mathrm{mL}$ (Dervis et al., 2009). The inoculated seedlings were transplanted into 4-inch pots filled with moist Sunshine $\mathrm{N} \& \mathrm{O}$ potting mix. Noninoculated reference control plants of each entry also were included, and were dipped in deionized water.

Disease ratings were taken on 10,16 , and 22 DAI using the following rating scale: $1=$ healthy, asymptomatic plant; $2=$ one symptomatic leaf; 3 = two symptomatic leaves; $4=$ three symptomatic leaves; 5 = four symptomatic leaves; and $6=$ dead plant. The symptoms used for the ratings included chlorosis, necrosis, and wilting; the cotyledons were included as "leaves" in the rating. On 12 May in 2014 and 3 Mar. in 2015, stems from each
The greenhouse inoculation study was a completely randomized design with six single-plant replicates of each entry and an additional reference control plant of each entry. Data were analyzed using PROC RANK and PROC GLM in SAS $(\alpha=0.05)$ Fisher's LSD test was used to determine which of the entries differed significantly on each rating date $(\alpha=0.05)$. Final disease ratings from the two greenhouse studies were averaged and correlated with RAUDPC values from the field study using PROC CORR in SAS.

\section{Results}

Field assay. Verticillium wilt symptoms were observed on all entries in the field study. At season's end (18 Sept.), significant differences in disease severity were observed among entries $(P=0.0001)$. 'Sugar Baby' had the highest final disease severity (98\%), whereas PI 419016 had the lowest (4\%) (Table 2). 'Sugar Baby' also had the highest RAUDPC value (26.80) but the value was not significantly different from 'Marvel' (14.57), PI 642045 (11.42), PI 368638 (10.84), '64-19 RZ' (7.14), and PI 634982 (6.85) $(P=$ $0.0001)$. PI 419060 had the lowest RAUDPC value (1.46) but RAUDPC was not significantly different from 'Miniature Bottle Gourd' (2.26), PI 419016 (2.39), PI 636137 (2.84), PI 536494 (3.33), 'Strong Tosa' (3.84), 'TZ 148' (3.97), 'Strongtosa' (4.00), and PI 326320 (4.27). There was no significant difference between the mean RAUDPC values of the commercial cultivars (5.68) and PI accessions (5.49) $(P=0.63)$.

Microsclerotia were observed on incubated stem samples of all entries except PI 181913 (Table 3). Of the 25 entries that yielded microsclerotia, typical Verticillium isolates were recovered from 16 . Of these, seven were selected and identified to the species level. Isolates obtained from 'Sugar Baby' and PI 419060 were identified as $V$. dahliae, whereas the other five isolates (obtained from '64-19 RZ', PI 604505, 'Rampart', 'Tetsukabuto', and 'Titan') were identified as $V$. isaacii Inderbitzin et al.

Greenhouse assays. In the greenhouse assays, there were interactions between year and DAI $(P=0.005)$ and between year and entry $(P<0.0001)$; thus, data for the two studies were analyzed separately. In both years, there were significant differences in disease ratings among entries for every rating date (Table 4). At 10 DAI in 2014, one entry (PI 438548) had a significantly higher disease rating than all others $(P=0.01)$, whereas seven entries were asymptomatic. At $16 \mathrm{DAI}$, PI 438548 again had the highest disease rating (2.67) but the rating was not significantly different compared with 'Sugar Baby' (2.50), 'Titan' (1.83), 'Marvel' (1.83), PI 419016 (1.67), or PI 536494 (1.83) $(P=$ $0.01)$. Two entries-PI 636137 and PI 181913 -remained asymptomatic at $10 \mathrm{DAI}$. At 22 DAI, 'Sugar Baby' surpassed PI 438548 with the highest disease rating (4.33 and 3.00 , respectively), but these entries did 
Table 3. Results from stem incubation assays for Verticillium sp., including detection of microsclerotia, recovered isolates, and species identification for selected entries from the verticillium wilt field screening study at Washington State University (WSU) Mount Vernon Northwestern Washington Research and Extension Center in 2013.

\begin{tabular}{|c|c|c|c|}
\hline Entry & $\mathrm{MS}^{\mathrm{z}}$ & Isolate $^{y}$ & Species $^{\mathrm{xw}}$ \\
\hline 64-19 RZ & Yes & JAW13-108 & Verticillium isaacii \\
\hline Emphasis & Yes & - & - \\
\hline Marvel & Yes & JAW13-224 & - \\
\hline Miniature Bottle Gourd & Yes & - & - \\
\hline PI 181913 & No & - & - \\
\hline PI 326320 & Yes & - & - \\
\hline PI 368638 & Yes & JAW13-121 & - \\
\hline PI 381820 & Yes & - & - \\
\hline PI 419016 & Yes & - & - \\
\hline PI 419060 & Yes & JAW13-301 & Verticillium dahliae \\
\hline PI 419123 & Yes & JAW13-228 & - \\
\hline PI 438548 & Yes & - & - \\
\hline PI 482490 & Yes & JAW13-322 & - \\
\hline PI 536494 & Yes & JAW13-223 & - \\
\hline PI 604505 & Yes & JAW13-113 & V. isaacii \\
\hline PI 634982 & Yes & JAW13-123 & - \\
\hline PI 636137 & Yes & JAW13-327 & - \\
\hline PI 642045 & Yes & - & - \\
\hline Rampart & Yes & JAW13-226 & V. isaacii \\
\hline RS 841 & Yes & JAW13-311 & - \\
\hline Strongtosa & Yes & JAW13-202 & - \\
\hline Strong Tosa & Yes & - & - \\
\hline Sugar Baby & Yes & JAW13-127 & V. dahliae \\
\hline Tetsukabuto & Yes & JAW13-306 & V. isaacii \\
\hline Titan & Yes & JAW13-110 & V. isaacii \\
\hline TZ 148 & Yes & JAW13-222 & - \\
\hline
\end{tabular}

${ }^{\mathrm{z}} \mathrm{MS}$ refers to microsclerotia.

y"__ " indicates that a pure isolate was not obtained.

xIsolates were identified to the species level at WSU Molecular Biosciences Laboratory in Puyallup, WA.

w" _ " indicates that the isolate was not sent to the laboratory for identification.

not differ significantly from 'Titan' and PI $419060(P=0.002)$. Only entry PI 636137 remained asymptomatic 22 DAI. In addition, all reference control plants remained asymptomatic, with the exception of 'Titan' and 'Marvel', which each received a rating of 2.00 on the final rating date. In 2015, 'Sugar Baby' had a significantly higher disease rating than all other entries at 10,16 , and 22 DAI $(P=0.003,0.003$, and 0.007 , respectively) and had a final rating of 4.33. At 22 DAI, none of the other entries differed significantly from one another, and all showed some symptoms of verticillium wilt. The incubation assay yielded $V$. dahliae on all inoculated entries in both greenhouse studies, whereas no $V$. dahliae was recovered from the stems of the noninoculated reference control plants. The final disease ratings from the greenhouse studies and RAUDPC values from the field study were found to be positively correlated $\left(r^{2}=0.81 ; P=0.001\right)$.

\section{Discussion}

'Sugar Baby' had the highest verticillium wilt rating in both the field and greenhouse studies confirming that it is highly susceptible to this disease (Elena, 2000). Of the 25 nonwatermelon entries included in the field study, 20 had significantly lower RAUDPC values than 'Sugar Baby'. In the first greenhouse study, all but three of the entries had significantly lower disease ratings than 'Sugar Baby' at 22 DAI, whereas in the second greenhouse study all entries had significantly lower disease ratings than
'Sugar Baby' at 22 DAI. Furthermore, all species included in this study (C. moschata, B. hispida, L. siceraria, and Cucurbita hybrid) had entries with significantly lower verticillium wilt ratings than 'Sugar Baby'. Thus, there is a wide diversity of species available that potentially could be used as rootstocks to manage verticillium wilt of watermelon in Washington.

Although there was a strong positive correlation between field and greenhouse studies, it is important to note that some entries performed differently in the two contrasting environments. For instance, PI 419060 had the lowest RAUDPC in the field, but was not significantly different from nongrafted 'Sugar Baby' in the greenhouse. The RAUDPC observed for 'Marvel' was not significantly different from that of 'Sugar Baby' in the field; however, in the greenhouse, the final disease rating of this rootstock was significantly lower than that of 'Sugar Baby'. Similarly, the RAUDPC observed for 'Titan' was significantly lower than that of 'Sugar Baby' in the field, whereas this rootstock did not have a significantly lower final disease rating than 'Sugar Baby' in the greenhouse. Although it has been reported that $V$. dahliae assays performed in greenhouse conditions can be used to predict field performance, results from this study suggest that rootstock reactions to this pathogen in the field may not always be consistent with reactions in the greenhouse. Factors contributing to the observed differences between field and greenhouse studies may include the differing light, water, and temperature levels in the two environments, as well as the presence of additional disease organisms in the field (Bae et al., 2011). In this study, temperatures during the field study were $16^{\circ} \mathrm{C}$ on average, with $22{ }^{\circ} \mathrm{C}$ maximum and $11{ }^{\circ} \mathrm{C}$ minimum, and $\mathrm{RH}$ was $81 \%$, whereas in the greenhouse, average temperature was 22 and $21{ }^{\circ} \mathrm{C}$ in 2014 and 2015, respectively $\left(24{ }^{\circ} \mathrm{C}\right.$ maximum and $20{ }^{\circ} \mathrm{C}$ minimum for both years), and RH was $40 \%$ and $42 \%$, respectively. Attempting to harmonize environmental conditions between the field and greenhouse may partially overcome this problem, although replicating the biological diversity of the field in the greenhouse would prove difficult.

Despite the inherent differences between greenhouse and field studies, both testing environments can nonetheless be used to assess levels of verticillium wilt resistance or tolerance among potential rootstocks. In the field study, all but one entry (PI 181913) were found to be infected with at least one Verticillium sp. and all entries displayed at least some verticillium wilt symptoms. In the first greenhouse study, PI 636137 demonstrated no verticillium wilt symptoms; however, all entries were found to be infected. In the second greenhouse study, all entries displayed verticillium wilt symptoms and all were found to be infected. Thus, none of the entries included in these studies could be classified as completely resistant; instead, entries were determined to have varying levels of tolerance to $V$. dahliae (Shurtleff and Averre, 1997). A similar finding was reported by Paplomatas et al. (2000), who found many rootstocks (zucchini, pumpkin, and bottle gourd varieties) to be tolerant of but not entirely resistant to $V$. dahliae. Follow-up studies conducted by Paplomatas et al. (2002) and Wimer et al. (2015) showed that grafting onto such tolerant rootstocks could delay verticillium wilt onset and increase yield. Relying exclusively on tolerant rootstocks should be avoided, however, as this practice could ultimately increase (or at least maintain) the $V$. dahliae soil population density (Louws et al., 2010; Robb, 2007).

The PI accessions included in this study had comparable verticillium wilt resistance to the commercial rootstock cultivars. This result suggests that these PI accessions could be used directly as rootstocks to manage verticillium wilt in Washington, or they could be used in domestic rootstock breeding programs to develop new verticillium wilttolerant rootstock cultivars. The prospect of developing domestic rootstocks is of interest because the majority of commercial rootstocks are currently developed in Asia, and many cultivars (as well as breeding material) are not widely available in the United States or necessarily adapted to U.S. field conditions. Thus, PI accessions may present an avenue for the development of rootstocks that are better suited to regional conditions. In addition, domestically produced rootstocks would likely be more widely available and affordable compared with what is currently imported into the U.S. market. 
Table 4. Mean verticillium wilt ratings ${ }^{\mathrm{z}}$ for 11 rootstock entries and 'Sugar Baby', a verticillium wiltsusceptible watermelon control, inoculated with Verticillium dahliae ${ }^{\mathrm{y}}$ isolate 'JAW13-127'x in a verticillium wilt greenhouse screening study at Washington State University (WSU) Mount Vernon Northwestern Washington Research and Extension Center (NWREC) in 2014 (and repeated in 2015).

\begin{tabular}{|c|c|c|c|c|}
\hline \multirow[b]{2}{*}{ Entry } & \multicolumn{3}{|c|}{ Days after inoculation (DAI) } & \multirow[b]{2}{*}{ Reference control ${ }^{\mathrm{w}}$ (22 DAI) } \\
\hline & 10 & 16 & 22 & \\
\hline \multicolumn{5}{|r|}{ 为 } \\
\hline Sugar Baby & $1.67 \mathrm{~b}$ & $2.50 \mathrm{ab}$ & $4.33 \mathrm{a}$ & 1.00 \\
\hline Tetsukabuto & $1.00 \mathrm{~b}$ & $1.17 \mathrm{bc}$ & $1.50 \mathrm{def}$ & 1.00 \\
\hline Titan & $1.33 \mathrm{~b}$ & $1.83 \mathrm{ab}$ & $2.67 \mathrm{abc}$ & 2.00 \\
\hline Marvel & $1.33 \mathrm{~b}$ & $1.83 \mathrm{ab}$ & 2.00 bcde & 2.00 \\
\hline Strongtosa & $1.00 \mathrm{~b}$ & $1.17 \mathrm{bc}$ & $1.33 \mathrm{def}$ & 1.00 \\
\hline PI 326320 & $1.00 \mathrm{~b}$ & $1.33 \mathrm{bc}$ & $1.50 \mathrm{def}$ & 1.00 \\
\hline PI 419016 & $1.00 \mathrm{~b}$ & $1.67 \mathrm{abc}$ & 2.17 bcde & 1.00 \\
\hline PI 419060 & $1.00 \mathrm{~b}$ & $1.83 \mathrm{bc}$ & $2.50 \mathrm{abcd}$ & 1.00 \\
\hline PI 438548 & $2.50 \mathrm{a}$ & $2.67 \mathrm{a}$ & $3.00 \mathrm{ab}$ & 1.00 \\
\hline PI 536494 & $1.50 \mathrm{~b}$ & $1.83 \mathrm{abc}$ & $2.00 \mathrm{cdef}$ & 1.00 \\
\hline PI 636137 & $1.00 \mathrm{~b}$ & $1.00 \mathrm{c}$ & $1.00 \mathrm{f}$ & 1.00 \\
\hline PI 181913 & $1.00 \mathrm{~b}$ & $1.00 \mathrm{c}$ & $1.17 \mathrm{ef}$ & 1.00 \\
\hline$P$ value $^{v}$ & 0.01 & 0.03 & 0.002 & \\
\hline \multicolumn{5}{|l|}{2015} \\
\hline Sugar Baby & $3.50 \mathrm{a}$ & $4.33 \mathrm{a}$ & $4.33 \mathrm{a}$ & 1.00 \\
\hline Tetsukabuto & $1.17 \mathrm{bc}$ & $1.33 \mathrm{bc}$ & $1.33 \mathrm{~b}$ & 1.00 \\
\hline Titan & $1.83 \mathrm{~b}$ & $1.83 \mathrm{~b}$ & $1.83 \mathrm{~b}$ & 1.00 \\
\hline Marvel & $1.83 \mathrm{~b}$ & $1.83 \mathrm{~b}$ & $2.00 \mathrm{~b}$ & 1.00 \\
\hline Strongtosa & $1.00 \mathrm{c}$ & $1.00 \mathrm{c}$ & $1.17 \mathrm{~b}$ & 1.00 \\
\hline PI 326320 & $1.17 \mathrm{bc}$ & $1.17 \mathrm{bc}$ & $1.17 \mathrm{~b}$ & 1.00 \\
\hline PI 419016 & $1.50 \mathrm{bc}$ & $1.67 \mathrm{~b}$ & $1.83 \mathrm{~b}$ & 1.00 \\
\hline PI 419060 & $1.33 \mathrm{bc}$ & $1.33 \mathrm{bc}$ & $1.33 \mathrm{~b}$ & 1.00 \\
\hline PI 438548 & $1.40 \mathrm{bc}$ & $1.80 \mathrm{bc}$ & $1.80 \mathrm{~b}$ & 2.00 \\
\hline PI 536494 & $1.40 \mathrm{bc}$ & $1.40 \mathrm{bc}$ & $1.40 \mathrm{~b}$ & 1.00 \\
\hline PI 636137 & $1.67 \mathrm{bc}$ & $1.83 \mathrm{~b}$ & $1.83 \mathrm{~b}$ & 1.00 \\
\hline PI 181913 & $1.17 \mathrm{bc}$ & $1.17 \mathrm{bc}$ & $1.17 \mathrm{~b}$ & 1.00 \\
\hline$P$ value & 0.003 & 0.003 & 0.007 & \\
\hline
\end{tabular}

${ }^{2}$ Ratings were conducted using a nonparametric rating scale: $1=$ healthy, asymptomatic plant; $2=$ one symptomatic leaf; $3=$ two symptomatic leaves; $4=$ three symptomatic leaves; $5=$ four symptomatic leaves; and 6 = dead plant. The symptoms used for the ratings included chlorosis, necrosis, and wilting, and the cotyledons were included as "leaves" in the rating.

${ }^{y}$ Seedlings at the 1-2 true leaf stage were inoculated using the root-dip method and a conidial suspension of $10^{6} / \mathrm{mL}$ (Dervis et al., 2009).

'JAW13-127' was isolated from 'Sugar Baby' during the 2013 field study at WSU Mount Vernon NWREC.

${ }^{w}$ One reference control plant was included for each entry. These control plants were inoculated with deionized water rather than the spore suspension.

vThe data were analyzed using PROC RANK and PROC GLM in SAS (Version 9.2, SAS Institute, Cary, NC) with $\alpha=0.05$. However, the means presented in the table are nontransformed. Fisher's LSD test was used to locate differences in treatment means. Treatment means followed by the same letter within a column are not significantly different at $\alpha=0.05$.

Although results from these field and greenhouse studies suggest that it may be possible to manage verticillium wilt of watermelon with the use of tolerant rootstocks, field studies with grafted plants are needed in Washington to further characterize this potential. Such grafted studies would elucidate any interactions that might exist between these rootstocks and the commonly used watermelon cultivars in Washington's diverse production regions. In addition, the compatibility of the PI accessions with watermelon needs to be assessed before they could be considered for commercial use. Lastly, considering data from the rootstock screening studies (both field and greenhouse) as well as grafted field studies would allow for a more accurate assessment of rootstock performance and utility in Washington.

\section{Literature Cited}

AgWeatherNet. 2013. Washington State University Mount Vernon and 10 Mile Station Historic Data. 29 Nov. 2013. <http://weather.wsu.edu/>. potato early dying. Phytopathology $84(8)$ : 792-800.

Davis, A.R., P. Perkins-Veazie, Y. Sakata, S López-Galarza, J.V. Maroto, S. Lee, Y. Huh, Z. Sun, A. Miguel, S.R. King, R. Cohen, and J. Lee. 2008. Cucurbit grafting. Crit. Rev. Plant Sci. 27(1):50-74.

Dervis, S., H. Yetisir, F.M. Tok, S. Kurt, and F. Karaca. 2009. Vegetative compatibility groups and pathogenicity of Verticillium dahliae isolates from watermelon in Turkey. Afr. J. Agr. Res. 4(11):1268-1275.

Elena, K. 2000. Vegetative compatibility among Verticillium dahliae isolates from watermelon in Greece. Phytoparasitica 28(2):115-120.

Fry, W.E. 1978. Quantification of general resistance of potato cultivars and fungicide effects for integrated control of potato late blight. Phytopathology 68:1650-1655.

Harris, D.C., J.R. Yang, and M.S. Ridout. 1993. The detection and estimation of Verticillium dahliae in naturally infested soil. Plant Pathol. 42:238-250.

Kabir, Z., R.G. Bhat, and K.V. Subbarao. 2004 Comparison of media for recovery of Verticillium dahliae from soil. Plant Dis. 88(1):49-55.

King, S.R., A.R. Davis, W. Liu, and A. Levi. 2008 Grafting for disease resistance. HortScience 43:1673-1676

King, S.R., A.R. Davis, X. Zhang, and K. Crosby. 2010. Genetics, breeding and selection of rootstocks for Solanaceae and Cucurbitaceae. Sci. Hort. 127:106-111.

Kirk, R.E. 1982. Experimental design. 2nd ed. Wadsworth, Belmont, CA

Klosterman, S.J., Z.K. Atallah, G.E. Vallad, and K.V. Subbarao. 2009. Diversity, pathogenicity, and management of Verticillium species. Annu. Rev. Phytopathol. 47:39-62.

Kubota, C., M.A. McClure, N. Kokalis-Burelle, M.G. Bausher, and E.N. Rosskopf. 2008. Vegetable grafting: History, use and current technology status in North America. HortScience 43:1664-1669.

Lee, J., H. Bang, and H. Ham. 1998. Grafting of vegetables. J. Jpn. Soc. Hort. Sci. 67(6):10981104.

Lee, J., C. Kubota, S.J. Tsao, Z. Bie, P. Hoyos Echevarria, L. Morra, and M. Oda. 2010. Current status of vegetable grafting: Diffusion, grafting techniques, automation. Sci. Hort. 127:93-105.

Louws, F.J., C.L. Rivard, and C. Kubota. 2010 Grafting fruiting vegetables to manage soilborne pathogens, foliar pathogens, arthropods and weeds. Sci. Hort. 127:127-146.

Miguel, A., J.V. Maroto, A. San Bautista, C. Baixauli, V. Cebolla, B. Pascual, S. Lopez, and J.L. Guardiola. 2004. The grafting of triploid watermelon is an advantageous alternative to soil fumigation by methyl bromide for control of Fusarium wilt. Sci. Hort. 103:9-17.

Paplomatas, E.J., K. Elena, and A. Tsagkarakou. 2000. Screening tomato and cucurbit rootstocks for resistance to Verticillium dahliae. EPPO Bul. 30:239-242.

Paplomatas, E.J., K. Elena, A. Tsagkarakou, and A. Perdikaris. 2002. Control of Verticillium wilt of tomato and cucurbits through grafting of commercial varieties on resistant rootstocks. Acta Hort. 579:445-449.

Paroussi, G., F. Bletsos, G.A. Bardas, J.A. Kouvelos, and A. Klonari. 2007. Control of Fusarium and Verticillium wilt of watermelon by grafting and its effect on fruit yield and quality. Acta Hort. 729:281-285.

Robb, J. 2007. Verticillium tolerance: Resistance, susceptibility, or mutualism? Can. J. Bot. 85:903-910. 
Sakata, Y., T. Ohara, and M. Sugiyama. 2007. The history and present state of the grafting of cucurbitaceous vegetables in Japan. Acta Hort. 731:159-170.

Shurtleff, M.C. and C.W. Averre, III. 1997. Glossary of plant-pathological terms. The American Phytopathological Society, St. Paul, MN

Sunseri, M. and D.A. Johnson. 2001. Verticillium wilt. Wash. State Univ. Coop. Ext. Bul. EB1908, Pullman WA.
University of California. 2010. SoilWeb: Online soil survey browser. California Soil Resource Lab. Davis, CA. 29 Apr. 2014. <http://calsoilresource. lawr.ucdavis.edu/>.

U.S. Environmental Protection Agency. 2013. The phaseout of methyl bromide. Ozone Layer Protection-Regulatory Programs. 16 July 2013. <http://www.epa.gov/ozone/mbr/>.

Wimer, J., D. Inglis, and C. Miles. 2015. Evaluating grafted watermelon for Verticillium wilt severity, yield, and fruit quality in
Washington State. HortScience 50:13321337.

Woodward, J.E., T.A. Wheeler, M.G. Cattaneo, S.A Russell, and T.A. Baughman. 2011. Evaluation of soil fumigants for management of Verticillium wilt of peanut in Texas. Online. Plant Health Prog. doi: 10.1094/PHP-2011-0323-02-RS.

Zhang, Y., M. Kyle, T. Zitter, and K. Anagnostou. 1997. Screening melon (Cucumis melo) for resistance to gummy stem blight in the greenhouse and field. HortScience 32:117-121. 